\title{
LUBUKLINGGAU'S ULU ALPHABET AND ITS PRESERVATION
}

\author{
Yeni Asmara, Sukardi \\ STKIP PGRI LUBUKLINGGAU \\ UNIV.PGRI PALEMBANG \\ yeni.stkip@gmail.com
}

\begin{abstract}
Abstrak
Aksara Ulu merupakan aksara yang digunakan oleh masyarakat daerah pesisir Sumatera yaitu etnis Pasemah, Serawai, Rejang, dan Lembak yang zaman dahulu difungsikan sebagai media dalam penyampaian nilai-nilai kearifan lokal, menceritakan suatu kisah, mencatat hukum adat, menulis sajak atau syair, menyampaikan ajaran agama, pengobatan, ataupun petuah. Pengaruh budaya asing di era globalisasi saat ini, dapat menyebabkan adanya perubahan kebudayaan sehingga terjadinya degradasi budaya lokal seperti Aksara Ulu yang keberadaannya semakin hilang eksistensinya terutama di beberapa daerah salah satunya Kota Lubuklinggau. Aksara Ulu tidak begitu familier di kalangan masyarakat terlebih lagi para pelajar sebagai generasi muda yang seharusnya aksara tersebut perlu dilestarikan dan dikembangkan dengan melalui berbagai upaya seperti melalui sosialisasi dan pembelajaran baik lingkungan formal maupun informal dalam kehidupan masyarakat sehingga aksara tersebut keberadaannya akan terus bertahan karena masyarakat pendukungnya tetap konsisten dalam memfungsikan aksara ulu sebagai identitas lokal yang harus dilestarikan.
\end{abstract}

\section{Kata Kunci : Aksara Ulu, Pelestarian}

\begin{abstract}
The Ulu alphabet by the Sumatra coastal communities, namely the Pasemah, Serawai, Rejang, and Lembak ethnic groups, which is functioned as media in delivering local wisdom values, telling a story, recording customary law, writing poems or poetry, conveying the teachings of religion, medicine, or advice. The influence of foreign culture in the current era of globalization does not rule out the possibility of local cultural degradation such as Ulu alphabet whose existence is almost vanished, especially in some areas, one of which is in Lubuklinggau. Ulu alphabet is not very common for the public, especially for the students as the young generation who should have preserved the alphabet and developed it through various efforts such as the introduction of reading and writing Ulu alphabet both in formal and informal environments in people's lives so that they remain exist and not eroded by the current development of the world.
\end{abstract}

Keywords: Ulu Alphabet, Preservation 


\section{A. PENDAHULUAN}

Aksara dalam pengertian umum merupakan suatu simbol yang dapat divisualisasikan ke dalam kertas ataupun media lainnya seperti daun, kayu, batu, bambu, dan lain sebagainya. Aksara merupakan alat komunikasi yang digunakan suatu masyarakat untuk melukiskan sesuatu baik secara tersirat maupun tersurat dalam rangka ingin mengetahui alam sekitarnya walaupun secara konkretnya tidak mengalami. Dengan adanya aksara manusia dapat mengetahui peristiwa-peristiwa yang telah terjadi (Roza, 2017:10). Aksara juga dianggap sebagai induk dari sebuah peradaban manusia. Seperti yang dijelaskan Megawati (dalam Simanjuntak,2015:5) pada saat memberikan sambutan diskusi Pameran dan Workshop "Kaligrafi Aksara Nusantara" di Galeri Nasional Indonesia, Jakarta pada 8 September 2015. Pahlawan dkk (2018:94) menjelaskan bahwa sebuah bangsa untuk mendapat pengakuan telah memiliki tingkat peradaban tinggi salah satu syarat utamanya adalah adanya aksara yang digunakan sebagai alat komunikasi.

Seperti yang telah dijelaskan sebelumnya bahwa aksara merupakan bagian dari unsur kebudayaan manusia yang menunjukkan identitas suatu masyarakat dalam sebuah peradaban manusia, karena aksara difungsikan sejak awal kehidupan manusia alat yang penting untuk melakukan kontak sosial. Dengan demikian aksara menjadi sebuah bukti dari kejayaan sebuah peradaban manusia (Arief Ikhsanudin,2015:8). Keberadaan aksara daerah yang merupakan salah satu warisan budaya bangsa dari masyarakat zaman lampau yang di dalamnya mengandung nilai-nilai kearifan lokal harus dijaga dan dilestarikan agar suatu bangsa tidak kehilangan identitas dan jati dirinya terutama di era globalisasi saat ini.

Indonesia yang dikenal sebagai negara kepulauan memiliki beragam warisan budaya 
yang pada umumnya dimiliki oleh daerah-daerah di wilayah nusantara seperti aksara atau tulisan asli yang ditemukan di berbagai daerah. Aksara nusantara merupakan aksara yang digunakan secara khusus untuk menuliskan bahasa daerah tertentu (Erwin, 2014:52). Di antara aksara nusantara tersebut adalah Aksara Ulu yang digunakan oleh masyarakat yang berada di wilayah Sumatera Selatan. Aksara Ulu telah berkembang pada abad ke 17-19 Masehi yang difungsikan sebagai alat rekam dalam suatu sistem simbol visual bahasa bagi suatu bangsa yang diperuntukkan dalam mengekspresikan diri.

Aksara Ulu salah satu jenis tulisan atau huruf yang digunakan oleh masyarakat daerah pesisir Sumatera yaitu etnis Pasemah, Serawai, Rejang, dan Lembak. Aksara Ulu dalam perkembangannya memiliki banyak jenis di antaranya aksara Ulu Serawai, aksara Ulu Pasemah, aksara Ulu Rejang, aksara Ulu Lembak, aksara Ulu Palembang, dan aksara Ulu Lampung (Sarwono, S. dalam Miranda,2014:5). Pada zaman dahulu Aksara Ulu dapat difungsikan sebagai media dalam penyampaian nilai-nilai kearifan lokal, menceritakan suatu kisah, mencatat hukum adat, menulis sebuah sajak atau syair, menyampaikan ajaran agama, pengobatan, ataupun petuah. Aksara Ulu yang ditemukan ditulis di bambu dan kulit kayu. Seperti yang ditemukan di Situs Ulak Lebar Aksara Ulu ditulis pada kepingan Bambo atau oleh masyarakat lokal disebut dengan Gelupai (Syam, 2015:35).

Di tengah kemajuan zaman dan masuknya ideologi asing sehingga terjadi perubahan sosial yang diikuti dengan perubahan kebudayaan. Ketika generasi muda tidak mampu untuk memahami budayanya sendiri maka bukanlah suatu hal yang tidak mungkin unsur-unsur kebudayaan asing dapat lebih menarik untuk dipelajari dan diadopsi oleh suatu generasi tertentu. Demikian pula 
dengan Aksara Ulu sebagai bagian dari budaya daerah, bagian dari budaya bangsa yang keberadaannya semakin hilang eksistensinya terutama di beberapa daerah salah satunya Kota Lubuklinggau. Aksara Ulu tidak begitu familier di kalangan masyarakat terlebih lagi para pelajar sebagai generasi muda khususnya di wilayah Lubuklinggau, seharusnya aksara daerah tersebut perlu dilestarikan dan dikembangkan sehingga diharapkan dapat memberikan kontribusi positif dalam kehidupan masyarakat, misalnya dapat dijadikan sebagai peningkatan kesejahteraan melalui kreativitas masyarakat melalui aksara ulu seperti pembuatan suvenir bertuliskan aksara ulu yang belum ada di wilayah Lubuklinggau sebagai ciri khas daerah. Di samping itu perlunya upaya pelestarian aksara ulu tersebut diharapkan agar aksara ulu dapat bertahan di tengah persaingan kebudayaan yang ada sebagai akibat dari adanya kemajuan Ilmu
Pengetahuan dan Teknologi saat ini. Penelitian mengenai aksara daerah terutama Ulu sudah pernah dilakukan sebelumnya oleh para ahli aksara, tetapi sayangnya aksara tersebut hanya diketahui oleh pihak-pihak tertentu saja tidak dibudayakan kepada masyarakat pendukung aksara tersebut sehingga suatu hal yang wajar jika masyarakat dalam hal ini generasi muda seperti pelajar tidak mengenal aksara daerah salah satunya adalah Ulu, yang merupakan sebuah identitas bangsa yang menunjukkan sebuah peradaban.

Kurangnya kesadaran dari beberapa pihak untuk membudayakan Aksara Ulu sebagai langkah konkret dalam pelestarian budaya daerah menyebabkan aksara tersebut terlupakan bahkan tidak diketahui oleh masyarakat pendukungnya saat ini, masyarakat lebih mengenal dan menyukai untuk mempelajari aksara dari luar seperti Latin, Mandarin, Arab dan lain sebagainya. Uraian di atas 
menunjukkan adanya kendala yang dihadapi untuk melestarikan aksara tersebut terutama di daerah Lubuklinggau seperti yang dikemukakan oleh Rusmana Dewi dalam wawancara dengan Linggau Pos bahwa upaya pelestarian aksara ulu atau Ka Ga Nga di Kota Lubuklingau masih terkendala di antaranya adalah sebagian besar masyarakat belum mengerti dan paham dengan aksara ulu tersebut [Linggau Pos Online [ 3 Des 2017] yang disampaikan Oleh karena itu penelitian ini perlu dilakukan sebagai upaya memberikan informasi kepada masyarakat seperti para akademisi, para peneliti dan pengambil kebijakan untuk mengambil langkah konkret dalam melestarikan aksara ulu agar dapat bertahan keberadaannya di zaman globalisasi saat ini. Seperti yang diuraikan sebelumnya jika tidak ada pihak yang mendukung upaya pelestarian aksara daerah tersebut maka yang dapat dimungkinkan akan terjadi adalah aksara daerah ulu hanyalah bagian dari sejarah di masa lalu yang tidak perlu dilestarikan dan bangsa pada umumnya akan kehilangan identitas atau jati dirinya.

\section{B. METODE PENELITIAN}

Metode

penelitian

merupakan cara yang ditempuh peneliti untuk menganalisis data, gejala, fenomena ataupun faktafakta mengenai apa yang akan diteliti. Adapun metode penelitian yang digunakan yaitu metode deskriptif yang mencoba memberikan gambaran mengenai suatu kondisi, kejadian, bahan tertentu atau segala sesuatu yang terkait dengan fakta-fakta atau kejadian secara sistematis dan akurat. Dengan menggunakan teknik kepustakaan dalam pengumpulan data-data yaitu penulis mengumpulkan sumbersumber data literatur dan hasil penelitian yang relevan dengan masalah yang ditulis (Nawawi, 2003:133).

\section{PEMBAHASAN}

1. Sejarah Aksara Di Nusantara

Pada uraian sebelumnya telah dijelaskan bahwa salah satu unsur 
dari sebuah bahasa yang dijadikan sebagai sarana dalam melakukan interaksi sosial bagi manusia, maka aksara yang difungsikan untuk menuangkan suatu ide atau gagasan dapat diketahui oleh orang atau kelompok lain tentang apa yang menjadi ide atau gagasan. Aksara menurut pengertian Kamus Besar Bahasa Indonesia diartikan sebagai tanda grafis atau fonem yang difungsikan oleh manusia sebagai anggota masyarakat untuk melakukan komunikasi sebagai salah satu syarat terjadinya kontak sosial. Aksara menurut bahasa Arab diartikan sebagai lambang bunyi atau dikenal dengan "sistem tulisan". Pengertian lain dari kata aksara diambil dari bahasa Sanskerta yang terdiri dari dua akar yaitu kata (a) yang memiliki arti tidak dan akar kata kshara yang berarti termusnahkan, maka kata aksara mempunyai arti sesuatu yang tidak ter musnahkan, bersifat kekal, atau langgeng dikarenakan aksara dijadikan alat untuk mendokumentasikan atau mengabadikan suatu kejadian yang telah berlangsung atau dialami manusia dalam bentuk tulisan.

Sementara itu pengklasifikasian aksara di dalam penjelasan Ensiklopedi yaitu (1) jenis piktografi suatu jenis aksara yang digunakan pada masyarakat Mesir dan Tiongkok Purba, (2) jenis ideografik seperti yang digunakan oleh masyarakat Tiongkok (3) jenis silabik yaitu aksara yang menggambarkan suku-suku kata seperti Pallawa, Devanagari, Jawa, Arab, Katakana, dan Hiragana Jepang; dan (4) dan jenis fonetik seperti aksara yang digunakan oleh masyarakat Rusia, Gothik dan Jerman (Roza, 2017:177-204).

Kebudayaan Hindu Budha yang terjadi melalui proses difusi di nusantara pada abad ke 4 Masehi telah memberikan pengaruh besar dalam kehidupan masyarakat nusantara seperti terjadinya perubahan pada periodisasi mengenai dari prasejarah ke zaman sejarah bagi masyarakat nusantara dengan ditemukannya batu bersurat atau 
prasasti Yupa di Kalimantan Timur yang bertuliskan aksara Pallawa dengan bahasa yang digunakan adalah bahasa yang digunakan oleh golongan Brahmana yaitu bahasa Sansekerta yang telah berkembang sebelumnya di India Selatan ( Nastiti,2014:1-80).

Pada umumnya aksara daerah yang terdapat di wilayah Indonesia merupakan turunan dari aksara yang berkembang pada masyarakat di India Selatan yaitu Aksara Pallawa yang merupakan turunan dari Aksara Brahmi yang dianggap sebagai induk bagi semua aksara yang terdapat di wilayah Asia Selatan dan Asia Tenggara (Igama Rapani, 2014:3). Pendapat di atas menjelaskan bahwa aksara yang berkembang di nusantara merupakan pengaruh budaya India ditinjau dari aspek bahasa atau sastra. Dalam perkembangannya Aksara Nusantara yang merupakan turunan dari aksara Pallawa kemudian menurunkan aksaraaksara daerah dengan menyesuaikan pada dialek yang digunakan masyarakat lokal bangsa Indonesia seperti aksara Kawi, Hanacaraka Batak, Bugis, Sunda, Ulu (Ka Ga Nga) . Berikut Gambar perkembangan silsilah aksara di nusantara.

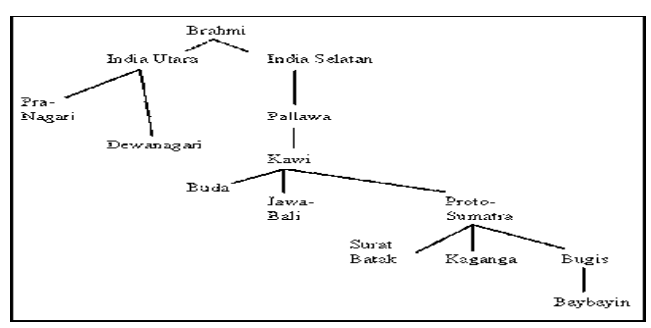

\section{Gambar 1.1. Silsilah Aksara Nusantara}

Dilihat dari bentuk variasi aksara daerah yang berkembang di nusantara seperti aksara Pallawa, aksara Kawi dan Hanacaraka tidak begitu jauh letak perbedaannya. Berikut tabel dari variasi aksara Pallawa, Kawi dan Hanacaraka.

\begin{tabular}{|c|c|c|c|c|c|c|c|c|c|c|c|c|c|}
\hline \multicolumn{4}{|c|}{ PALLAVA } & \multicolumn{5}{|c|}{ KAWI } & \multicolumn{5}{|c|}{ JAWA } \\
\hline kd & ${ }_{k h}^{8} ?$ & $\stackrel{\text { du }}{\mathrm{gh}}$ & $\begin{array}{l}\Sigma_{\mathrm{ng}} \\
\text { n }\end{array}$ & ก & co & $\begin{array}{l}n \\
g\end{array}$ & m & $\begin{array}{c}c \\
\mathrm{ng}\end{array}$ & $\begin{array}{c}a m \\
k\end{array}$ & $\begin{array}{c}\text { an } \\
k h\end{array}$ & $\underset{g}{m}$ & $g \mathrm{gn}$ & $\begin{array}{l}m \\
\mathrm{ng}\end{array}$ \\
\hline $\begin{array}{l}\text { D } \\
c\end{array}$ & $\begin{array}{lll}\sigma_{0} & \approx \\
\text { ch } & j\end{array}$ & $j_{j h}^{p}$ & $\int_{\text {ny }}^{p}$ & $\begin{array}{c}D \\
C\end{array}$ & $\begin{array}{l}\text { o } \\
\mathrm{ch}\end{array}$ & $\epsilon$ & $\mho_{\mathrm{jh}}$ & m & ${ }_{c}^{a r}$ & $\begin{array}{l}\text { oser } \\
\text { ch }\end{array}$ & ${ }_{j}^{\infty}$ & वृ & ny \\
\hline th & $c_{\text {thh }}^{c} c$ & in 6 & $\begin{array}{l}m \\
n h\end{array}$ & th & $\underset{\text { thh }}{c}$ & $\underset{\text { ddh }}{\sigma}$ & $\underset{\text { thi }}{G}$ & $\underset{n h}{m}$ & $\begin{array}{l}\text { w } \\
\text { th }\end{array}$ & the & $\begin{array}{l}\text { a) } \\
\text { ddth }\end{array}$ & $\begin{array}{l}\text { an } \\
\text { dh }\end{array}$ & $\begin{array}{c}\mathrm{mm} \\
\mathrm{nh}\end{array}$ \\
\hline $\begin{array}{c}\alpha \\
t \\
t\end{array}$ & $\begin{array}{cc}\omega_{0} & C \\
\text { th } & \end{array}$ & dh & $\begin{array}{l}\alpha \\
n\end{array}$ & a & $\begin{array}{l}\text { G) } \\
\text { th }\end{array}$ & $\begin{array}{l}\text { a } \\
\text { d }\end{array}$ & $\begin{array}{c}\oplus \\
\text { dh }\end{array}$ & $\begin{array}{l}\delta \\
n\end{array}$ & ๘n & th & and & $\begin{array}{l}\text { an } \\
\mathrm{dh}\end{array}$ & ${ }_{n}^{a n}$ \\
\hline u & $\begin{array}{ccc}2 & 0 \\
\mathrm{ph} & \mathrm{b}\end{array}$ & on & $\begin{array}{l}\mathrm{d} \\
\mathrm{m}\end{array}$ & $u_{p}$ & $\underset{\mathrm{ph}}{v}$ & $\begin{array}{l}0 \\
0 \\
b\end{array}$ & $\begin{array}{c}\hat{n} \\
\mathrm{bh}\end{array}$ & ध & ${ }_{\mathrm{P}}^{\mathrm{ur}}$ & $\begin{array}{l}\text { as } \\
\text { ph }\end{array}$ & $\underset{b}{c m}$ & $\begin{array}{l}\boldsymbol{x} \\
\text { bh }\end{array}$ & $\begin{array}{l}\text { El } \\
\mathrm{m}\end{array}$ \\
\hline & $\begin{array}{ll}0 & 2 \\
1 & 1\end{array}$ & O & & $\begin{array}{c}w \\
y\end{array}$ & $\begin{array}{l}9 \\
r\end{array}$ & $\tilde{w}_{1}$ & $\stackrel{\circ}{w}$ & & $\begin{array}{c}w_{y} \\
y\end{array}$ & n & $\frac{\mathrm{mu}}{1}$ & $\begin{array}{l}\text { un } \\
\text { w }\end{array}$ & \\
\hline & $\underset{\text { Sh }}{E} d$ & $\begin{array}{lll}y_{s} & \text { Ln }\end{array}$ & & $\underset{\text { sy }}{\text { }}$ & $\underset{\mathrm{sh}}{\Theta}$ & ${ }_{S}^{N}$ & ${ }_{n}^{n}$ & & $\underset{\text { sy }}{\boldsymbol{m}}$ & $\begin{array}{l}\text { at. } \\
\text { sh }\end{array}$ & $\begin{array}{c}\text { an } \\
\text { s }\end{array}$ & $\begin{array}{l}\text { an } \\
h\end{array}$ & \\
\hline
\end{tabular}

Tabel 1.2. Aksara Pallawa, Kawi dan Hanacaraka Berdasarkan hasil penelitian yang telah dilakukan oleh beberapa ahli menyimpulkan 
bahwa aksara nusantara menyebar ke beberapa wilayah di nusantara yang kemudian berkembang seperti di wilayah Jawa, Sunda dan Bali menggunakan aksara Kawi dan Hanacaraka. Untuk di wilayah Bengkulu, Lampung, Sumatera Selatan seperti darah Rejang, Lembak, Serawai, dan Pasemah, kemudian Kerinci aksara yang berkembang adalah aksara Ka Ga Nga atau sebagian mengenal dengan Aksara Ulu. Selanjutnya di wilayah Karo, Pak-Pak, Toba, Simalungun, Angkola-Mandailing menggunakan Aksara Batak. Kemudian di wilayah Bugis, Bima dan Makassar masyarakatnya menggunakan aksara Sulawesi.

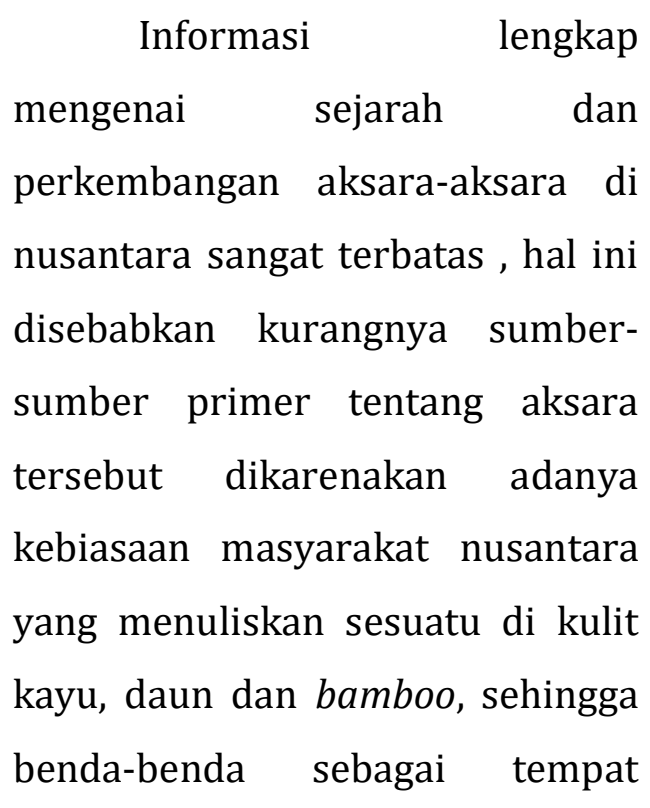

menulis tersebut tidak dapat bertahan lama, mudah lapuk, yang menyebabkan para peneliti kesulitan untuk melakukan identifikasi, rekonstruksi dan analisis sejarah secara rinci tentang aksara yang berkembang di wilayah tersebut.

\section{Aksara Ulu Lubuklinggau}

Untuk masyarakat yang tinggal di wilayah pedalaman seperti Bengkulu, Jambi, Palembang menggunakan Aksara Ulu. Lebih lanjut lagi oleh E.E. Mc. Kinon dalam Sulaiman, 2011:8) menjelaskan bahwa sekitar 10002000 tahun yang lalu, di daerah bagian Hulu Sungai Batang Hari telah dijadikan sebagai tempat tinggal oleh suku bangsa yang disebut Keling, diperkirakan berasal dari India dengan tujuan untuk mencari emas. Gelombang berikutnya dilanjutkan pada abad ke-13, dengan datangnya bangsa India kembali ke daerah Melayu di Jambi, pada saat itu mereka menemukan orang-orang di Kerajaan Melayu sudah mempunyai bentuk tulisan sendiri 
yang disebut dengan Aksara Rencong, yang orang India ataupun China tidak mengerti dengan tulisan tersebut.

Sebagian daerah yang berada di wilayah Sumatera mengenal Aksara Ulu sebagai sebutan Aksara Rencong dikarenakan cara penulisan hurufnya mengalami kemiringan sekitar 45 derajat misalnya di Jambi dikenal dengan aksara Incung, Aceh dikenal dengan aksara rencong, Sumatera Utara dikenal dengan aksara Pustaha dan di Sulawesi dikenal sebagai aksara Lontar. Masing-masing daerah memiliki nama yang berbeda-beda terkait dengan pelafalan aksara Ka Ga Nga atau Ulu maka untuk memberikan kemudahan dalam mengingat dan mempermudah pelafalan terhadap aksara tersebut secara nasional maka disebutlah aksara rencong.

Aksara Ulu banyak ditemukan pada bahan-bahan yang terbuat dari bambu dan kulit kayu atau disebut dengan kakhas, ada juga sebagian aksara tersebut ditulis pada rotan, lontar, kulit hewan, dan tanduk Igama (2014:3). Berdasarkan hasil penelitian Titik Pudjiastuti (2018:94) bahwa Umumnya naskah ulu Palembang menggunakan bahan naskah dari kulit pohon halim atau gelumpai. Seperti yang telah dijelaskan sebelumnya aksara ulu merupakan tulisan yang digunakan oleh masyarakat pada zaman lampau yaitu diperkirakan telah muncul abad ke-9 dan mengalami perkembangan abad ke-13 di wilayah Sumatera Selatan. Aksara tersebut digunakan oleh masyarakat yang tinggal di daerah bagian hulu Sungai Musi dan aliran Sungai Musi (anak Sungai) misalnya Sungai Komering, Lematang, Rawas, Rupit, Lakitan, Kelingi dan Beliti termasuk wilayah Lubuklinggau yang pada waktu lampau dikenal dengan daerah Musi Rawas. Oleh karena masyarakat tersebut tinggal di wilayah bagian hulu Sungai dan anak sungai Musi maka masyarakat tersebut sering 
dikenal dengan masyarakat Uluan sehingga tulisannya pun lebih dikenal dengan sebutan Aksara Ulu. Aksara Ulu atau dikenal juga dengan aksara Ka Ga Nga pada zaman dahulu banyak digunakan oleh golongan masyarakat tertentu seperti keluarga pesirah, dukun, golongan intelektual maupun pemuka agama. Oleh karena itu Aksara Ulu pada masanya difungsikan oleh masyarakat yang menggunakannya sebagai media dalam mengkomunikasikan mengenai peristiwa yang telah berlangsung, untuk menyampaikan ajaran agama yang berkembang pada waktu itu atau sebagai sarana dalam penyampaian mengenai kearifan lokal.

Harimurti (dalam Sarwit Sarwono, 2010:10) menjelaskan bahwa aksara ulu atau yang lebih dikenal dengan aksara rencong atau sebutan lainnya adalah aksara Ka Ga Nga dapat diklasifikasikan sebagai syllabic system yaitu sistem penulisan dengan menggunakan satu lambang penyebut dengan fonem merangkap konsonan dan vocal yang terdiri dari 16 huruf konsonan - vokal yaitu Ka, Ga, Ta, $\mathrm{Da}, \mathrm{Na}, \mathrm{Pa}, \mathrm{Ba}, \mathrm{Ma}$, Ca, Ja, Sa, Ra, La, Ya, Wa, Ha dan 9 huruf konsonankonsonan-vokal Nga, Nya, Mba, Mpa, Nca, Nta, Nda, Nja, Gha lalu 2 lambang huruf konsonankonsonan-konsonan-vokal (Ngga, Ngka) serta 1 lambang huruf vokal (A), tiap huruf dapat berubah penyebutannya sesuai tata letak kunci penanda baca. Huruf-huruf ditulis dengan ditarik ke kanan atas sampai sekitar 45 derajat.

Pada dasarnya, aksara daerah yang menyebar dan berkembang di masyarakat berasal dari sumber yang sama, kemudian dalam perkembangannya aksara tersebut disesuaikan dengan kebutuhan dan keperluan dalam berbahasa yang menyesuaikan dengan tingkat perkembangan kebudayaan masing-masing daerah, sehingga terjadi perubahan-perubahan pada huruf dan tanda eja, oleh karena itu menimbulkan perbedaan pada beberapa huruf dan tanda eja 
setiap masing-masing daerah yang memiliki aksara tersebut misalnya di Bengkulu Aksara Ulu dikenal dengan aksara Ka Ga Nga, di Jambi aksara Incung, di Aceh aksara Rencong.

Dari penelitian yang telah dilakukan Suwandi Syam (2015:35) penemuan Aksara Ulu pertama kali yaitu ditemukan di Situs Ulak Lebar, aksara tersebut dituliskan pada beberapa bilah bambu yang oleh masyarakat lokal Lubuklinggau disebut gelupai berjumlah delapan keping. Aksara Ulu yang dituliskan pada Gelupai tersebut adalah sebuah terjemahan naskah kuno yang menggunakan bahasa Sansekerta dan bercampur bahasa Melayu Kuno.

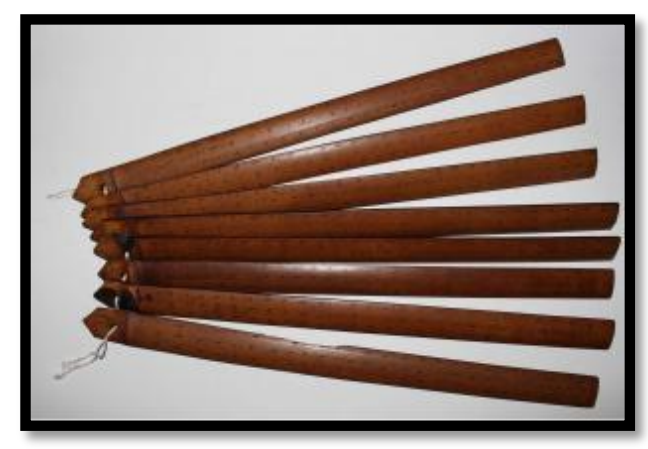

Gambar 1.3. Naskah Gelupai, ditemukan di Situs Ulak Lebar.
Tersimpan di Museum Balaputra Dewa, Palembang. Adapun hasil transliterasi dan terjemahan dari Naskah Gelupai tersebut dapat di lihat di bawah ini:

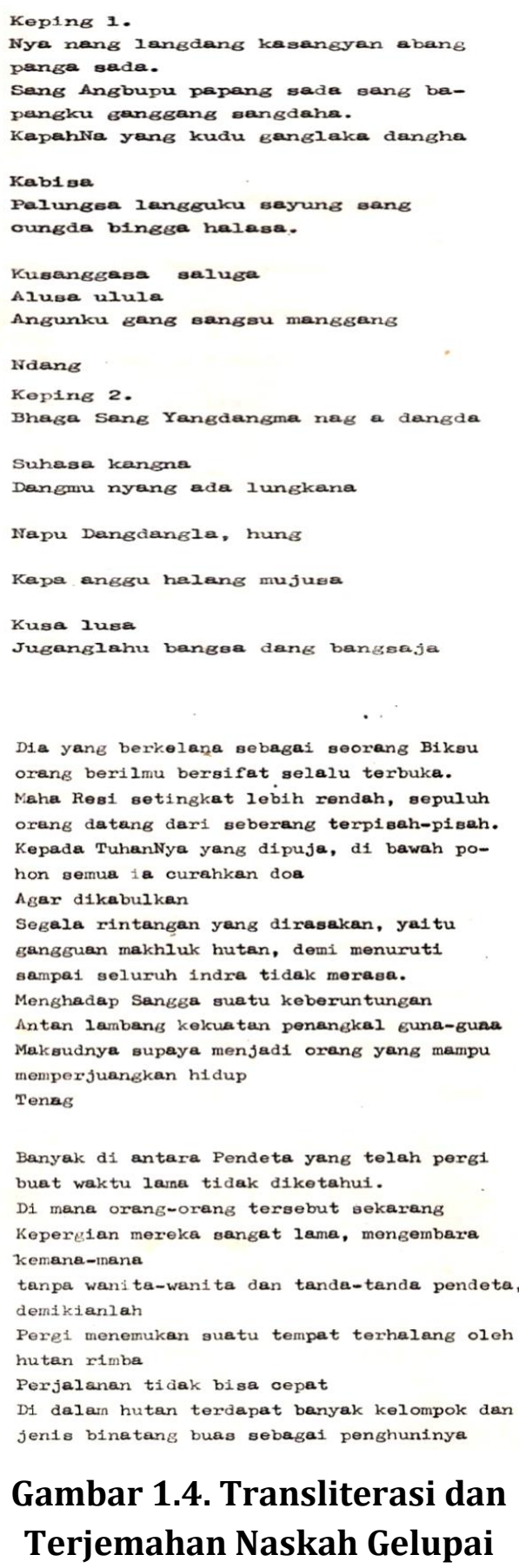

Gambar 1.4. Transliterasi dan Terjemahan Naskah Gelupai 
Terbatasnya sumber-sumber yang dapat menjelaskan tentang sejarah Aksara Ulu membuat beberapa penelitian tentang aksara tersebut belum mampu mendeskripsikan mengenai data awal sejarah dan perkembangan aksara ulu di Lubuklinggau dalam hal ini belum dapat diketahui secara jelas sejak kapan Aksara Ulu tersebut masuk ke daerah seperti Bengkulu dan menyebar ke daerah sekitarnya, siapa dan dari golongan mana yang membawanya, serta bagaimana cara penyebarannya sampai saat sekarang ini belum dapat terungkap dengan jelas.

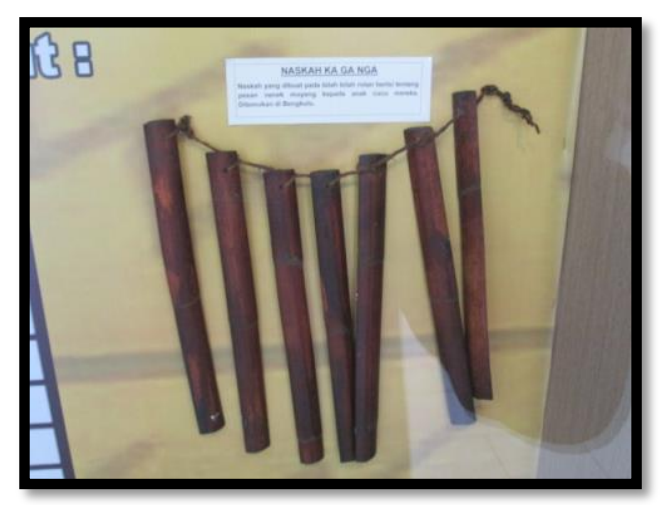

Gambar 1.7. Naskah Ka Ga Nga, terbuat dari Bilah Rotan. (Lokasi: Museum Negeri Bengkulu, Kota Bengkulu)
Berikut bentuk aksara Ulu, yang dikenal dengan juga dengan istilah aksara $\mathrm{Ka}$ Ga Nga atau aksara rencong di beberapa wilayah yang berada di wilayah Sumatera.

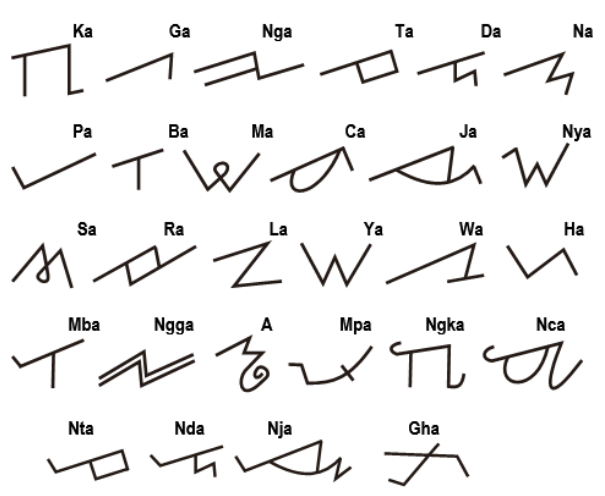

Gambar 1.8. Sketsa Huruf Ulu Khas Kota Lubuklinggau

Dari sketsa huruf Ulu di atas langkah berikutnya agar dapat membantu dalam menulis dan membacanya adalah dengan memahami penggunaan Kunci Penanda Baca yang dilambangkan dengan huruf [Ka] yang berlaku juga untuk semua huruf ulu yang lainnya ketika membuat atau membaca suatu kata atau kalimat. 


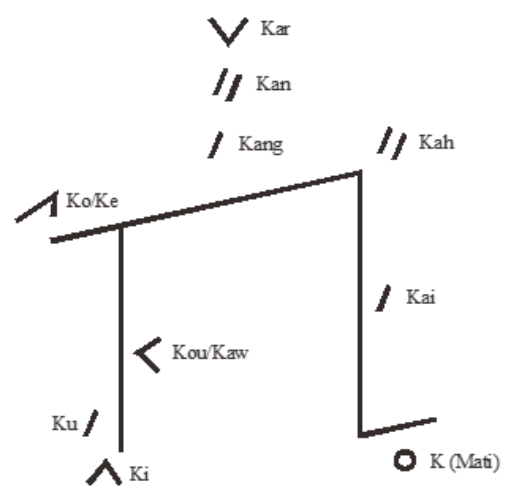

Gambar 1.9. Kunci Penanda Baca, dengan awalan huruf "Ka" 3. Upaya Pelestarian Aksara Ulu

Penelitian mengenai upaya pelestarian aksara daerah telah dilakukan Aziz Ahmad (2017:23) yang menjelaskan pentingnya peran serta warga negara untuk melestarikan aksara daerah sebagai salah satu warisan budaya yang tidak lagi dipraktikkan atau diwacanakan oleh masyarakat pendukungnya, sehingga sangat dikhawatirkan lambat laun generasi penerus tidak mengenal aksara daerahnya. Adapun manfaat mempelajari aksara daerah dijadikan sebagai alat komunikasi yang efektif seperti komunikasi bersifat "rahasia" dalam arti kata hanya dapat dipahami secara terbatas bagi yang menulis dan menerima pesan dengan menggunakan aksara tersebut. Dengan adanya upaya pelestarian aksara daerah dapat menjadikan aksara sebagai alat komunikasi tertulis yang dapat digunakan oleh masyarakat seperti aksara pada umumnya. Apabila dicermati penggunaan aksara ulu ini sangat menarik apabila dipelajari bahkan perlu dikembangkan agar dapat kembali eksistensinya di era zaman globalisasi saat ini.

Pelestarian suatu budaya diperlukan peran dari pihak-pihak tertentu seperti orang yang ahli tentang aksara daerah, misalnya peneliti, guru, pemerintah dan masyarakat. Adanya pihak-pihak yang telah memahami aksara diharapkan dapat memperkenalkan dan mengajarkan kepada generasi muda tentang bagaimana cara menulis dan membaca Aksara Ulu baik dengan menyediakan buku teks atau buku ajar tentang menulis dan membaca Aksara Ulu untuk keperluan pembelajaran yang dapat disimpan di 
perpustakaan sekolah sebagai buku referensi dan sebagai buku pengayaan. Upaya berikutnya dapat dilakukan melalui pendidikan informal seperti adanya kursus-kursus yang diberikan oleh sekelompok komunitas pecinta aksara daerah atau pendidikan formal seperti melalui sekolah dengan mengintegrasikan pembelajaran Aksara Ulu dalam kegiatan ekstrakurikuler atau pelajaran muatan lokal seperti yang dijelaskan pada Peraturan Mendikbud bahwa muatan lokal merupakan kurikulum yang berisi tentang potensi dan kondisi budaya daerah yang dapat dipelajari oleh siswa yang berada di daerahnya masing-masing.

$$
\text { Muatan lokal yang }
$$

dijadikan sebagai bagian dari kurikulum memiliki tujuan di antaranya adalah menjadikan sumber belajar yang ada di daerah dapat memberikan kontribusi positif bagi kepentingan pendidikan, dapat dimanfaatkan peserta didik untuk menerapkan pengetahuan dan keterampilan sebagai upaya memecahkan masalah dengan memanfaatkan potensi daerah yang ada. Di samping itu muatan lokal yang merupakan hasil pengintegrasian nilai-nilai kearifan lokal dalam lingkungan sekolah dapat mempersiapkan murid agar mereka memiliki wawasan yang mantap tentang lingkungannya serta sikap dan perilaku bersedia melestarikan dan mengembangkan sumber daya alam ,kualitas sosial, dan kebudayaan yang mendukung pembangunan nasional maupun pembangunan setempat Basari (2014:18-26).

Dari uraian di atas dapat diambil pengertian bahwa upaya melestarikan budaya daerah termasuk dalam hal ini adalah Aksara Ulu dapat dilakukan dengan cara mengintegrasikan aksara tersebut ke dalam pembelajaran di lingkungan sekolah seperti muatan lokal sehingga dapat mendukung pembangunan nasional maupun pembangunan daerah. Oleh karena 
itu diperlukan kerja sama oleh semua pihak untuk mewujudkan hal tersebut terutama pemerintah daerah untuk membuat Perda yang mengatur tentang upaya pelestarian budaya daerah seperti Aksara Ulu. Dengan demikian aksara tersebut dapat secara berangsur-angsur dapat dibudayakan oleh masyarakat bahkan dapat dijadikan sebagai sumber pendapatan bagi masyarakat misalnya melalui pembuatan suvenir seperti kaos bertuliskan aksara ulu, merek industri, atau cinderamata yang lainnya bahkan aksara daerah dapat dibudayakan kepada masyarakat luas melalui pembuatan papan nama pada jalan, perkantoran dan lain-lain sebagai upaya menjaga, mengembangkan dan melestarikan budaya daerah sebagai identitas dan nilai kearifan lokal suatu bangsa yang bernilai tinggi agar mampu bertahan, bersaing dan dapat menjadi daya tarik objek wisata aksara. Dapat dicontohkan, ketika percobaan menulis dengan kalimat “Sejarah” maka lambang huruf dilengkapi penanda bacanya dapat ditampilkan di bawah ini :

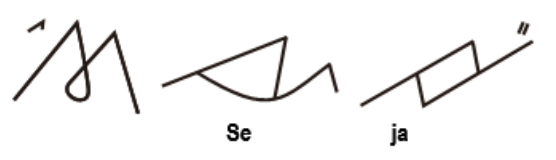

rah

\section{SIMPULAN}

Aksara Ulu salah satu jenis tulisan atau huruf yang digunakan oleh masyarakat daerah pesisir Sumatera yaitu etnis Pasemah, Serawai, Rejang, dan Lembak. Oleh karena masyarakat tersebut tinggal di wilayah bagian hulu Sungai dan anak sungai Musi maka masyarakat tersebut sering dikenal dengan masyarakat Uluan sehingga tulisannya pun lebih dikenal dengan sebutan Aksara Ulu. Aksara Ulu dalam perkembangannya memiliki banyak jenis di antaranya aksara Ulu Serawai, aksara Ulu Pasemah, aksara Ulu Rejang, aksara Ulu Lembak, aksara Ulu Palembang, dan aksara Ulu Lampung.

Keberadaan aksara daerah yang merupakan salah satu warisan budaya bangsa dari masyarakat zaman lampau yang di dalamnya mengandung nilai-nilai 
kearifan lokal harus dijaga dan dilestarikan agar suatu bangsa tidak kehilangan identitas dan jati dirinya terutama di era globalisasi saat ini.

Upaya melestarikan budaya daerah termasuk dalam hal ini adalah Aksara Ulu dapat dilakukan dengan cara mengintegrasikan aksara tersebut ke dalam pembelajaran di lingkungan sekolah seperti muatan lokal sehingga dapat mendukung pembangunan nasional maupun pembangunan daerah. Oleh karena itu diperlukan keraja sama oleh semua pihak untuk mewujudkan hal tersebut terutama pemerintah daerah untuk membuat Perda yang mengatur tentang upaya pelestarian budaya daerah seperti Aksara Ulu. Dengan demikian aksara tersebut dapat secara berangsur-angsur dapat dibudayakan oleh masyarakat bahkan dapat dijadikan sebagai sumber pendapatan bagi masyarakat misalnya melalui pembuatan suvenir seperti kaos bertuliskan aksara ulu, merk industri, atau cinderamata yang lainnya bahkan aksara daerah dapat dibudayakan kepada masyarakat luas melalui pembuatan papan nama pada jalan, perkantoran dan lain-lain sebagai upaya menjaga, mengembangkan dan melestarikan budaya daerah sebagai identitas dan nilai kearifan lokal suatu bangsa yang bernilai tinggi agar mampu bertahan, bersaing dan dapat menjadi daya tarik objek wisata aksara.

\section{DAFTAR REFERENSI}

Ahmad, Aziz, 2014. Melestarikan budaya tulis nusantara ;kajian tentang aksara lontar. Jurnal Budaya Nusantara, Vol.1 No.2, (Desember 2014): 148-153.

Basari, Achmad. 2014. Penguatan Kurikulum Muatan Lokal dalam Pembelajaran di Sekolah Dasar. Seminar Nasional ISBN: 978-6027561-89-2 (18-26)

Erwin, Alfian, 2014. Penggunaan Unsur Aksara Pada Huruf Kontemporer. Diakses 10 Desember2018 https://www.researchgat e.net/publication/327935 882_Penggunaan_Unsur_A 
ksara_Nusantara_Pada_Hu ruf_Modern

Igama, Rapani,Ahmad, 2014. Surat Ulu: Tradisi Tulis Masa Lalu Sumatera Selatan. Diakses 3 Desember 2018:https://lingdy.aaken.jp/wpcontent/uploads/2014/02 /140227-intl-symp-andws ahmad rapanie paper. $\underline{\mathrm{pdf}}$

Ikhsanudin, Arief, 2015. Historia Masa Lampau selalu Actual. Diakses 3 Desember 2018 http://historia.id.budaya.a $\underline{\text { rticles. }}$

Kozok, Uli. 2000. Manfaat Pemetaan dalam Menelusuri Kembali Sejarah Aksara Nusantara dalam Masyarakat Pernaskahan Nusantara. Tradisi Tulis Nusantara Menjelang Milenium III: Kumpulan Makalah Simposium Internasional Pernaskahan Nusantara III 1999. Jakarta: Masyarakat Pernaskahan Nusantara.

Lubuklinggau Post , 2017. Peletarian Aksara Ulu di Kota Lubuklinggau. Diterbitkan di Lubukinggau

Miranda,Reva,Eko, 2014. Skripsi. Pengembangan Transliterasiaksara Ulu Ke Aksara Latin Berbasis
Android. Universitas Bengkulu.

Nastiti ,Surti, Titi ,2014. Jejak-Jejak Peradaban Hindu Budha Di Indonesia. Kalpataru Majalah Arkeologi Vol 23 No 1 Mei 2014 :1-80

Nawawi, Hadari.2003. Metode Penelitian Bidang Sosial. Gajah Mada Universitas Press.

Pahlawan,dkk.2018. Efektivitas Media Aplikatif Dalam Pembelajaran Aksara "Ka Ga Nga" Sebagai Upaya Melestarikan Kearifan Lokal Suku Rejang Bengkulu Utara. Jurnal Program Kreatifitas Mahasiswa Vol 02, Nomor 02 ,hal:95

Pudjiastuti, Titik, 2018. Naskah Ulu Palembang. Diakses 28 November 2018 http://staff.ui.ac.id/syste m/files/users/titik.pudjias tuti/publication/naskahul upalembang.pdf

Roza, Ellya.2017. Aksara ArabMelayu di Nusantara dan Sumbangsihnya dalam Pengembangan Khazanah Intelektual . Tsaqafah Jurnal Peradaban Islam. Vol. 13, No. 1, Mei 2017, 177-204, ISSN 1475-4334.

$\begin{array}{rr}\text { Simanjuntak,2015. } & \text { Kaligrafi } \\ \text { Aksara } & \text { Nusantara. } \\ \text { Sindonews.com. } & \text { Diakses }\end{array}$


$22 \quad$ November 2018 https://nasional.sindonew s.com.

Sulaiman, Anas, Marzuki. 2011. Hanacaraka: Aksara Jawa yang Mulai Ditinggalkan. Surakarta: Institut Seni Indonesia.
Suwandi Syam (2015:35) Syam, Suwandi. 2015. Silabus dan Petunjuk Praktis Membaca dan Menulis Aksara Ulu (Aksara Rencong) Sumatera Selatan. Lubuklinggau: STKIP-PGRI Lubuklinggau. 